\title{
Impact of Demonetisation on Bank Stock
}

\author{
Triveni $\mathrm{P}^{\star}$ and Anupma Kumari ${ }^{\dagger}$
}

\section{Abstract}

This paper empirically examines the impact of demonetisation on Indian bank stock. On 8th November 2016, the Indian Prime Minister, Narendra Modi declared demonetisation in an unscheduled live broadcast. Currency notes of Rs 500 and Rs 1000 were demonetised from the midnight of $8^{\text {th }}$ November 2016. This was issued to curb black money and corruption. During demonetisation, the index values of the stock market SENSEX, NIFTY and BANKEX went down. This research mainly focusses on how demonetisation affected the stock price of the top Indian banks. With the help of CAAR, change in return and change in volatility, the effect of demonetisation on the stock market was calculated. Furthermore, an understanding of the impact of demonetisation on bank stocks was attempted. The evaluation helped in concluding that there has been no impact on the bank stocks post demonetisation.

Keywords: Demonetisation, CAAR, Bankex, Volatility

\section{Introduction}

Demonetisation has impacted the Indian stock market. The benchmark BSE Sensex fell nearly 1.5 per cent and the NSE index fell nearly 2 per cent to its lowest close in six months, dragged down by finance and auto stocks such as State Bank of India and

\footnotetext{
* Ramaiah Institute of Management, Bengaluru, India; triveni@msrim.org

† Ramaiah Institute of Management, Bengaluru, India; anupmagupta48@gmail.com
} 
Tata Motors. The benchmark BSE index ended at 385.10 points or 1.47 per cent at 25,765.14, its sixth consecutive session of decline. Nifty PSU Bank index surged as high as 9.5 per cent on Thursday, 9th November 2017 and hit a fresh 52-week high of 3,437.25 against the previous close of 3,137.90. Among the top gainers in the basket of public sector banks, Bank of India closed at 13.71 per cent (up at Rs 124.80), Union Bank (up 12.70 per cent), Punjab National Bank BSE 1.77 \% (up 11.92 per cent), Syndicate Bank (up 10.43 per cent) and Bank of Baroda (up 9.26 per cent). The shares of State Bank of India BSE - $0.77 \%$ (SBI), India's largest lender, surged 8.21 per cent to Rs 281.35 and hit a fresh 52-week high of Rs 284.20.

On the other hand, Nifty Private Bank index closed 2.74 per cent up at 11210.45. Major Private sector lenders like HDFC Bank (BSE 0.23 $\%$ ), ICICI Bank (BSE -1.34 \%), Axis Bank (BSE -0.85\%) and YES Bank (BSE $1.50 \%$ ) settled higher by $2.10 \%, 4.16 \%, 4.09 \%$ and $5.79 \%$ respectively.

\section{Literature review}

Sunil and Shenoy (2017) examined the impact of demonetisation on the stock of selected sectors like the automobile industry, the banking industry, the consumer durables industry, telecommunication industry and real estate industry. The study examined the expected return of the selected stock pre and post demonetisation using data from 6 months from the BSE index. The researchers suggested that demonetisation did not have any impact on stock returns.

The impact of demonetisation on Stock Price Movements in the banking sector of India deserves mention here. Dash and Bagha studied the reaction of India indices (Sensex, Nifty and Bankex) to demonetisation in India. The researcher took a random bank stock to analyse the data using the $\mathrm{Z}$ tool. They found that the stock prices did not show any significant effect of demonetisation in the short run.

Kakkad (2017) studied the impact of demonetisation and cashless transaction on the respondents of Rajkot. The objective of the study was to identify people's response towards cashless transaction and to find out the efforts undertaken by people towards building a 
cashless society. The primary data was collected using a convenience sampling method. The sample size was considered to be 100 respondents from Rajkot. He concluded that people strongly believed that demonetisation signified good signs for the development of India.

Veerakumar (2017) studied the impact of demonetisation on people. He attempted to describe the concept of demonetisation in India to understand the demographic profile of the respondents in Coimbatore district and to identify how the seelct section of people people reflected on demonitisation as a process. Analysing thedata collected through questinnaires by using statistical tools like simple percentage, chi-square test and ranking method, the study concluded that demonetisation was seen as an attempt to destroy black money.

\section{Statement of the problem}

The Indian economy performed well in 2016 and the stock market was at the highest point till October 2016. However, on $8^{\text {th }}$ November 2016, the Indian government decided to demonetise 500 and 1000 rupee notes. This affected the Indian stock market and had an impact on banking stocks, the currency market and the Indian economy. This study focusses on the impact of demonetisation on Indian banking stock.

\section{Objectives of the study}

The study tries to:

- Evaluate the performance of banking stocks for a period of 30 days prior to demonetisation

- Evaluate the performance of banking stocks for a period of 30 days post demonetisation

- Compare banking stock return and volatility with pre and post demonetisation for three months

- Measure the impact of demonetisation on S\&P BSE BANKEX 


\section{The scope of the study}

This study focusses on the impact of demonetisation on one-year stock prices, specifically with reference to the banking stock. Both public, as well as a private bank, have been considered for the study.

\section{Hypothesis}

H0: There is no significant effect of demonetisation on S\&P BSE BANKEX as compared to S\&P BSE SENSEX.

H1: There is a significant effect of demonetisation on S\&P BSE BANKEX as compared to S\&P BSE SENSEX.

\section{Methodology}

This study is analytical in nature. It is based on the secondary data collected through bank websites and stock markets- NSE index and BSE. The variables used to analyse the stock performance are CAAR, AAR, Volatility and Return.

\section{Data analysis}

The data collected from the websites and the stock markets have been analysed as follows:

\subsection{Objective 1}

To evaluate the performance of banking stocks for a period of 30 days prior to demonetisation 
Table 1 Return and Volatility Pre Demonetisation

\begin{tabular}{lcc}
\hline & Pre-Demonetisation Aggregate return for 30 days \\
\hline \multicolumn{1}{c}{ Banks } & Return & Volatility \\
Axis Bank & -0.002504 & 0.32143 \\
City Union Bank & 0.002848 & 0.226979 \\
HDFC Bank & 0.00039 & 0.144782 \\
ICICI Bank & 0.002348 & 0.330256 \\
IDFC Bank & 0.00619 & 0.295162 \\
IndusInd Bank & 0.000506 & 0.197489 \\
Kotak Mahindra & 0.000695 & 0.163067 \\
Allahabad Bank & -0.00127 & 0.380822 \\
Andhra Bank & -0.00117 & 0.354504 \\
Bank of Baroda & -0.00072 & 0.398109 \\
Bank of India & 0.000336 & 0.428513 \\
Canara Bank & 0.002764 & 0.388032 \\
Central Bank & -0.00147 & 0.340967 \\
Corporation Bk & -0.00028 & 0.238785 \\
IDBI Bank & 0.000744 & 0.397369 \\
IOB & -0.00113 & 0.253893 \\
PNB & 0.002578 & 0.424195 \\
SBI & 0.001511 & 0.301276 \\
Syndicate Bank & -0.00144 & 0.376854 \\
Vijaya Bank & 0.002514 & 0.411522 \\
\hline
\end{tabular}

\subsubsection{Return}

The above data indicates the return of the individual companies before demonetisation. Under the public sector, banks such as PNB (0.002578), SBI (0.001511) and Vijaya Bank (0.002514) yielded positive returns. However, Syndicate Bank (-0.00144) gave a negative return during the pre-demonetisation period.

Under the private sector, banks like City Union Bank (0.002848), HDFC Bank (0.00039), ICICI Bank (0.002348), IDFC Bank (0.00619), Induslnd Bank (0.000506) and Kotak Mahindra (0.000695) yielded positive returns during the pre-demonetisation period. However, certain private banks like AXIS Bank (-0.0025), Allahabad Bank (0.00127), Andhra Bank (-0.00117) and the Central Bank (-0.00147) gave a negative return during the pre demonetisation. 


\subsubsection{Volatility}

While looking at Table 1 , we can see changes in the value from 0.163067 to 0.428513 , which means that the volatility is not high. This further implies that the risk with these banks was not high during the pre-demonetisation period. Under the public sector, Banks like Bank of India (0.428513), PNB (0.424195), Vijaya Bank (0.411522) were more volatile during pre-demonetisation. While the private banks like HDFC Bank (0.144782), IndusInd Bank (0.197489) Kotak Mahindra (0.163067) were less volatile.

\subsubsection{Inference}

The analysis of the data of the performance of the banks during pre-demonetisation indicate that volatility and return are not directly proportional.

\subsection{Objective 2}

To evaluate the performance of banking stocks for a period of 30 days post-demonetisation

Table 2 Return and Volatility Post Demonetisation

\begin{tabular}{lll}
\hline & & Post-Demonetisation \\
\hline Banks & Return & Volatility \\
Axis Bank & 0.001552 & 0.304321 \\
City Union Bank & 0.00115 & 0.344892 \\
HDFC Bank & 0.002494 & 0.147749 \\
ICICI Bank & 0.00116 & 0.275953 \\
IDFC Bank & -0.0012 & 0.270741 \\
IndusInd Bank & 0.003308 & 0.205376 \\
Kotak Mahindra & 0.001302 & 0.215603 \\
Allahabad Bank & 0.001286 & 0.310639 \\
Andhra Bank & 0.00157 & 0.258846 \\
Bank of Baroda & 0.00064 & 0.369163 \\
Bank of India & 0.001766 & 0.28875 \\
Canara Bank & 0.00087 & 0.283037 \\
Central Bank & 0.000147 & 0.161686 \\
Corporation Bk & 0.000686 & 0.343294 \\
IDBI Bank & 0.002627 & 0.308292 \\
IOB & 0.001233 & 0.364289 \\
PNB & 0.000776 & 0.303816 \\
SBI & 0.000949 & 0.211987 \\
Syndicate Bank & 0.000865 & 0.269993 \\
Vijaya Bank & 0.008148 & 0.525283 \\
\hline
\end{tabular}




\subsubsection{Return}

Post demonetisation, IDFC Bank (-0.0012) return was found negative. All other banks performed positively. Banks such as Axis Bank, Allahabad Bank, Andhra Bank, IOB, Syndicate Bank yielded negative returns pre-demonetisation but post-demonetisation, Axis Bank (0.001552), Allahabad Bank (0.001286), Andhra Bank (0.00157), IOB (0.001233) and Syndicate Bank (0.000865) gave positive returns. Vijaya Bank (0.008148) yielded the maximum returns.

\subsubsection{Volatility}

Post demonetisation, when we look at volatility, the value remains at 0.147749 to 0.525283 , quite different when compared to predemonetisation values. While banks like HDFC Bank (0.147749) Central Bank (0.161686) were less volatile, Axis Bank (0.304321), City Union Bank (0.344892), Bank of Baroda (0.369163), IOB (0.364289) were high in volatility. Vijaya Bank (0.525283) was highly volatile.

\subsubsection{Inference}

Vijaya Bank yielded maximum return irrespective of their high volatility value. If demonetisation had an impact on stock return, the volatility values should have crossed 1, but the values remain between 0.147749 and 0.525283 . This indicates that volatility has little impact on bank stocks. Banks with negative returns predemonetisation changed into positive returns post-demonetisation.

\subsection{Objective 3}

To compare banking stock return and volatility with pre and post demonetisation for 30 days 
Table 3 Change in return and Volatility

\begin{tabular}{|c|c|c|c|c|c|c|}
\hline & \multicolumn{2}{|c|}{ Pre-Demonetisation } & \multicolumn{2}{|c|}{ Post-Demonetisation } & \multicolumn{2}{|c|}{ Change } \\
\hline Banks & Return & Volatility & Return & Volatility & Return & volatility \\
\hline Axis Bank & -0.002504 & 0.32143 & 0.001552 & 0.304321 & $-162 \%$ & $-5 \%$ \\
\hline $\begin{array}{l}\text { City Union } \\
\text { Bank }\end{array}$ & 0.002848 & 0.226979 & 0.00115 & 0.344892 & $-60 \%$ & $52 \%$ \\
\hline HDFC Bank & 0.00039 & 0.144782 & 0.002494 & 0.147749 & $539 \%$ & $2 \%$ \\
\hline ICICI Bank & 0.002348 & 0.330256 & 0.00116 & 0.275953 & $-51 \%$ & $-16 \%$ \\
\hline IDFC Bank & 0.00619 & 0.295162 & -0.0012 & 0.270741 & $-119 \%$ & $-8 \%$ \\
\hline $\begin{array}{l}\text { IndusInd } \\
\text { Bank }\end{array}$ & 0.000506 & 0.197489 & 0.003308 & 0.205376 & $554 \%$ & $4 \%$ \\
\hline $\begin{array}{l}\text { Kotak } \\
\text { Mahindra }\end{array}$ & 0.000695 & 0.163067 & 0.001302 & 0.215603 & $87 \%$ & $32 \%$ \\
\hline $\begin{array}{l}\text { Allahabad } \\
\text { Bank }\end{array}$ & -0.00127 & 0.380822 & 0.001286 & 0.310639 & $-201 \%$ & $-18 \%$ \\
\hline $\begin{array}{l}\text { Andhra } \\
\text { Bank }\end{array}$ & -0.00117 & 0.354504 & 0.00157 & 0.258846 & $-234 \%$ & $-27 \%$ \\
\hline $\begin{array}{l}\text { Bank of } \\
\text { Baroda }\end{array}$ & -0.00072 & 0.398109 & 0.00064 & 0.369163 & $-189 \%$ & $-7 \%$ \\
\hline $\begin{array}{l}\text { Bank of } \\
\text { India }\end{array}$ & 0.000336 & 0.428513 & 0.001766 & 0.28875 & $426 \%$ & $-33 \%$ \\
\hline $\begin{array}{l}\text { Canara } \\
\text { Bank }\end{array}$ & 0.002764 & 0.388032 & 0.00087 & 0.283037 & $-69 \%$ & $-27 \%$ \\
\hline $\begin{array}{l}\text { Central } \\
\text { Bank }\end{array}$ & -0.00147 & 0.340967 & 0.000147 & 0.161686 & $-110 \%$ & $-53 \%$ \\
\hline $\begin{array}{l}\text { Corporation } \\
\text { Bk }\end{array}$ & -0.00028 & 0.238785 & 0.000686 & 0.343294 & $-345 \%$ & $44 \%$ \\
\hline IDBI Bank & 0.000744 & 0.397369 & 0.002627 & 0.308292 & $253 \%$ & $-22 \%$ \\
\hline IOB & -0.00113 & 0.253893 & 0.001233 & 0.364289 & $-209 \%$ & $43 \%$ \\
\hline PNB & 0.002578 & 0.424195 & 0.000776 & 0.303816 & $-70 \%$ & $-28 \%$ \\
\hline SBI & 0.001511 & 0.301276 & 0.000949 & 0.211987 & $-37 \%$ & $-30 \%$ \\
\hline $\begin{array}{l}\text { Syndicate } \\
\text { Bank }\end{array}$ & -0.00144 & 0.376854 & 0.000865 & 0.269993 & $-160 \%$ & $-28 \%$ \\
\hline Vijaya Bank & 0.002514 & 0.411522 & 0.008148 & 0.525283 & $224 \%$ & $28 \%$ \\
\hline
\end{tabular}

Table 3 reports the result of the study of the impact of demonetisation on both private and public within a span of 30 days both during pre and post demonetisation.

Within 30 days of demonetisation, with respect to changes in return, we find that the bank stocks have not had much impact. There has been a mixed outcome; few banks have performed well and others have yielded a negative return. By looking at the data (Table 1), the accurate performance of a sector (public or private) cannot be concluded. 


\subsubsection{Analysing individual banks of private sector}

With respect to change in returns, demonetisation positively impacted both HDFC and INDUSIND banks. While HDFC (539\%) performed very well after demonetisation yielding good returns, IndusInd Bank (554\%) also delivered a similar result after demonetisation.

On the other hand, demonetisation had a negative impact on City Union Bank, ICICI Bank, Axis Bank, and IDFC Bank. Their returns were seen to reduce post-demonetisation. However, Kotak Mahindra Bank managed to provide positive returns to its investors.

\subsubsection{Analysing public sector banks}

PNB, SBI and CANARA BANK yielded fewer returns postdemonetisation. On the contrary, BANK OF INDIA and VIJAYA BANK yielded huge returns after demonetisation and their share price market values increased after demonetisation.

\subsection{Objective 4}

To measure the impact of demonetisation on S\&P, BSE and BANKEX in order to compare it to S\&P, BSE and SENSEX over a 3month period.

\subsubsection{Hypothesis}

H0: There is no significant effect of demonetisation on S\&P BSE BANKEX when compared to S\&P BSE SENSEX.

H1: There is a significant effect of demonetisation on S\&P BSE BANKEX when compared to S\&P BSE SENSEX. 
Table 4 Post Demonetisation

\begin{tabular}{|c|c|c|c|c|c|c|c|c|}
\hline & & & Post De & nonetisati & & & & \\
\hline & & & CAAR & alculation & & & & \\
\hline Date & Senser & Bankex & Return & & & t-test & & CAAR \\
\hline & Closing & Closing & Sensex & Bankex & 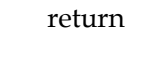 & & $\mathrm{f}$ & \\
\hline -Dec-16 & 26559.92 & 21067.72 & $-0.35 \%$ & $-1.16 \%$ & $-0.772 \%$ & -1.34113 & no & $-0.77 \%$ \\
\hline 2-Dec-16 & 230.66 & 20874.34 & $-1.24 \%$ & $-0.92 \%$ & $0.558 \%$ & 0.969 & no & \\
\hline 5-Dec-16 & 26349.1 & 21042.39 & $0.45 \%$ & $0.81 \%$ & $0.226 \%$ & 393722 & no & $0.01 \%$ \\
\hline 6-Dec-16 & 26392.76 & 21074.67 & $0.17 \%$ & $0.15 \%$ & $-0.078 \%$ & .13549 & no & $-0.07 \%$ \\
\hline 7-Dec-16 & 26236.87 & 20849.49 & $-0.59 \%$ & $-1.07 \%$ & $-0.381 \%$ & 0.66242 & no & $-0.45 \%$ \\
\hline 8-Dec-16 & 26694.28 & 21170.05 & $1.74 \%$ & $1.54 \%$ & -0 & & no & $-1.06 \%$ \\
\hline 9-Dec-16 & 26747.18 & 2141 & $0.20 \%$ & 1.1 & 0 & 55 & no & $-0.19 \%$ \\
\hline 12-Dec-16 & 2651 & 2105 & $-0.87 \%$ & -1.6 & -0.6 & -1.11836 & no & $-0.83 \%$ \\
\hline 13-Dec-16 & 26697.82 & 21156.16 & $0.69 \%$ & 0.48 & -0.3 & -0.6 & no & $-1.21 \%$ \\
\hline 14-Dec-16 & 26602.84 & 21038.51 & $-0.36 \%$ & $-0.56 \%$ & -0.1 & -0.26774 & no & $-1.37 \%$ \\
\hline 15-Dec-16 & 26519.07 & 2109 & $-0.31 \%$ & 0.2 & 0.6 & 124 & no & $-0.73 \%$ \\
\hline 16-Dec-16 & 2648 & 20 & $-0.11 \%$ & & & & no & $-1.17 \%$ \\
\hline 19-Dec-16 & & 20 & -0. & & & & no & $4 \%$ \\
\hline $20-\mathrm{C}$ & 26 & 2 & -0.2 & -1 & & & no & $3 \%$ \\
\hline 21-Dec-16 & 262 & 2065 & $-0.25 \%$ & 0.1 & & & no & $-1.52 \%$ \\
\hline 22-Dec-16 & 2597 & 204 & $-1.00 \%$ & & & 38 & no & $5 \%$ \\
\hline 23-Dec-16 & 26040.7 & 2042 & $0.24 \%$ & -0.1 & -0.4 & -0.81 & no & $-1.92 \%$ \\
\hline 26-Dec-16 & 25807.1 & 2014 & -0.90 & & -0 & -0.5 & no & $-2.23 \%$ \\
\hline 27-Dec-16 & 26213.44 & 20412.21 & 1.57 & 1.3 & -0.6 & -1.0 & no & $-2.86 \%$ \\
\hline 28-Dec-16 & 26210.68 & 20408.25 & $-0.01 \%$ & $-0.02 \%$ & -0.03 & -0.06376 & no & $-2.90 \%$ \\
\hline 29-Dec-16 & 26366.15 & 20564.71 & $0.59 \%$ & $0.77 \%$ & $0.016 \%$ & 0.027923 & no & $-2.88 \%$ \\
\hline 30-Dec-16 & 26626.46 & 20748.74 & $0.99 \%$ & $0.89 \%$ & $-0.334 \%$ & -0.5814 & no & $-3.22 \%$ \\
\hline 2-Jan-17 & 26595.45 & 20503.18 & $-0.12 \%$ & & & -1.86361 & no & $-4.29 \%$ \\
\hline 3-Jan-17 & 26643.24 & 20615.91 & $0.18 \%$ & & & 0.524043 & no & $-3.99 \%$ \\
\hline 4-Jan-17 & 26633.13 & 20446.24 & $-0.04 \%$ & & & -1.40277 & no & \\
\hline 5-Jan-17 & 268 & 20722.41 & $0.92 \%$ & & & 373 & no & $-4.59 \%$ \\
\hline 6-Jan-17 & 26759.23 & 20900.86 & $-0.44 \%$ & $0.86 \%$ & $1.369 \%$ & 2.379576 & yes & $-3.23 \%$ \\
\hline
\end{tabular}

Table 4 reports that demonetisation affected the S\&P BSE and BANKEX index because values of CAAR reached to $-3.23 \%$. This means that demonetisation which took place on $8^{\text {th }}$ November 2016, had a lasting effect till $6^{\text {th }}$ January 2017. The negative value which confirms the event having a significant influence on the performance of the stock in the BSE SENSEX and the $t$-test value $(<1.96)$ indicates that there is no impact on the individual day value of S\&P BSE BANKEX.

\subsubsection{Hypothesis testing}

At $5 \%$ level of significance, the t-value should be less than (1.96) or greater than 0.05 . However, in this situation, most of the values are 
less than (1.96) so the null hypotheses $\mathrm{H}_{0}$ will be accepted and $\mathrm{H}_{1}$ will be rejected. This indicates that demonetisation has had no significant effect on S\&P BSE BANKEX as compared against S\&P BSE SENSEX.

\section{Findings}

- The performance of the banks during pre demonetisation has indicated that volatility and return are not directly proportional.

- Vijaya Bank yielded maximum returns irrespective of a high volatility value.

- If demonetisation did have an impact on stock returns, the volatility values should have crossed 1 . But, the value remains between 0.147749 and 0.525283 . This indicates that there is less impact on the volatility of bank stocks.

\section{Conclusion}

The study helps to conclude that events like demonetisation do not affect the stock market in a major way. If the BSE SENSEX has seen a change in index, it does not mean that the entire sector under BSE SENSEX has experienced a change. Banks, both public and private do not yield similar returns when compared on the basis of the stock returns.

Therefore, if an event like demonetisation had an impact on the economy, it affected the middle class or merchants since they went cashless. However, it did not affect the stock market. Though public banks received a large amount of cash during demonetisation, it did not influence the bank stock return. In conclusion, we would like to offer a few suggestive measures. The investors who are wary of investing in bank stocks because of demonetisation could reflect on the study and understand that the returns of the investors might not be affected by such processes. Moreover, we suggest that investing in bank stock could yield a good return without involving a high risk, specifically, private bank stocks could yield better returns than public bank stocks. 


\section{Reference}

Sunil, T., \& Shenoy, S. V. (2017). Impact of demonetization on stocks of selected sectors - An event study. International Journal of Research in Finance and Marketing (IJRFM), 7(5), 29-38.

Dash, S. D., \& Bagha, P. (2017). Impact of demonetization on stock price movements in banking sector of India. International Journal of Research and Scientific Innovation (IJRSI), IV(VIIS), 33-36.

Kakkad, V. P. (2017). An empirical study on impact of the demonetisation and cashless transaction on the respondents of Rajkot city. Abhinav National Monthly Refereed Journal of Research in Commerce\& Management, 6(3), 1-9.

Veerakumar, K. (2017). A study on people impact on demonetization. International Journal of Interdisciplinary Research in Arts and Humanities, 2(1), 9-12. 